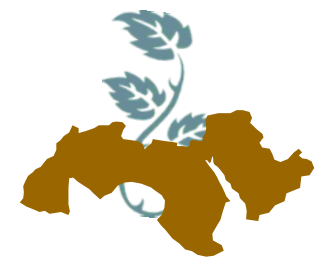

Arab Univ.

J. Agric. Sci., Ain Shams Univ., Cairo, 26(2), 657 - 666, 2018

\title{
APPLIED STUDY OF MICROBIOLOGICAL HAZARDS IN RAW MILK SOFT WHITE CHEESE IN EGYPT
}

\author{
Maha F. Lotfy ${ }^{1}$; O.A. Aita ${ }^{2}$; Enas A. Hassan ${ }^{1}$ and Azhar A. Elsayed ${ }^{1}$ \\ 1- Agricultural Microbiology Dept., Fac. of Agric., Ain Shams Univ., Cairo, Egypt \\ 2- Food Science Dept., Fac. of Agric., Ain Shams Univ., Cairo, Egypt
}

Keywords: Raw milk soft white cheese, Domaiti cheese, Pathogenic bacteria, Microbiological hazards

\section{ABSTRACT}

Raw milk Domiati cheese is the main soft white pickled cheese produced in Egypt. The objective of this study was to assess the microbiological hazards, physiochemical quality and safety of some raw Domiati cheese subtypes including Double Cream, Tallaga, Baramely and Istanbully. The cheese samples were randomly collected from different cheese retailers in Cairo. The results indicated that the protein content and fat content were high in Double cream cheese. The $\mathrm{pH}$ value was low in Baramely cheese. Total solid, ash, and EC were high in Istanbully cheese because it is high salt level. Also, results indicated high microbiological hazards. the cheese samples were highly contaminated, having microbial load exceeding the acceptable limits such as: Total bacterial count, Total coliform, Fecal E. coli and yeast \& molds. Pathogenic bacteria (Staphylococcus aureus, E. coli 0157:H7, Salmonella sp., Shigella sp., Listeria monocytogenes, Bacillus cereus and Campylobacter jejuni) were detected in three cheese samples. Except Istanbully cheese sample were found free of most pathogenic bacteria. A high microbial load of the cheese samples present a public health hazard to the consumers and emphasize the need for improving hygienic standard. Microbiological hazards must be limited to the stander limit of food safety. Raw milk soft white cheese must be manufactured according to hygienic standard.

\section{INTRODUCTION}

The cheese is an excellent source of protein, amino acids, calcium, phosphorus, vitamins and many micronutrients (CDIC, 2014). In Egypt, different cheese types are mainly produced from cow and buffalo's raw milk. Domiati cheese is the most popular soft white cheese, which represents about $75 \%$ of the cheese produced and consumed in Egypt (El-Baradei et al 2007). It is similar to the soft cheese of east European countries. It is consumed fresh or ripened (pickled for 3 months). Domiati cheese is made from buffalo's and cow's milk, with high salt levels up to $15 \%$.

In modern factories, Domiati cheese is made from pasteurized recombined milk with vegetable fat and less salt levels (1-5\%). According to the Egyptian Standards (1008-3/2005), the moisture content should not exceed $60 \%$ and the salt contents should not exceed $9 \%$ in Domiati cheese. Additionally, the cheese should be free from harmful additives and pathogens such as, Salmonella $\mathrm{sp}$, Staphylococcus aureus, Clostridium botulinum, Listeria monocytogenes, Campylobacter jejuni, Bacillus cereus, Escherichia coli O157:H7, Sreptococcus faecalis and indicator hygiene include Coliform group and fungi shouldn't exceed $10 \mathrm{cfu} / \mathrm{g}$ and the yeast shroud not exceed $400 \mathrm{cfu} / \mathrm{g}$. according to the manufacturing processes, there are many subtypes of Domiati cheese. Tallaga cheese is made with low salt level and ripened refrigerated. Baramely cheese with additional 48- 72 hours at room temperature. The salt level (15 - 17\%) added in Istanbully cheese is the highest among Domiati cheese subtypes. Double cream cheese is the subtype with highest moisture and fat with a

(Received 1 August, 2017) 
very soft body and texture. There were many outbreaks of infections associated with the consumption of cheese. The predominant organisms identified were Salmonella sp., Listeria monocytogenes, Escherichia coli and Staphylococcus aureus (De Buyser et al 2001; (Nummer et al (2012). Such sources might be during cheese production, storage or from human contamination, air, milking equipment, feed, soil, feces and grass (Gould et al 2014). There are many researches related to the determination of Physio-chemical quality of cheese but there are only a few researches conducted to detect microorganisms that cause quality problems in raw soft white cheese in Egypt and microbiological hazards (Hegazy et al 2012 and El-Baradei et al 2007). The aim of this study are: identify of the microbiological hazards in raw milk soft white cheese.

\section{MATERIALS AND METHODS}

\section{Sampling}

Different Domiati cheese varieties were sampled from Cairo retails. The cheese varieties (Raw milk) include Double Cream, Tallaga, Baramely and Istanbully raw milk soft white cheeses (seven samples each). The cheeses were kept at $4{ }^{\circ} \mathrm{C}$, transported to the laboratory and analyzed within $24 \mathrm{~h}$ samples receiving.

\section{Physiochemical Analysis}

Fat content, total solids and ash content were determined in collected samples according to (AOAC 2006). Salt content was determined according to APHA (1992). Protein content of cheese was determined by measuring the total nitrogen content of samples by the Kjeldahl method and multiplying by a conversion factor 6.38 APHA (1992). The $\mathrm{pH}$ values were determined using bench - top $\mathrm{pH}$ meters, HANNA Model $\mathrm{HI}-$ 9321. Titrable acidity (as a lactic acid) was determined according to AOAC (2006). Electric Conductivity $(E C)$ was measured at $25^{\circ} \mathrm{C}$ as standard temperature using ATC bench EC meter, HANNA Model HI-8820.

\section{Microbiological Analysis}

\subsection{Microbial count}

Total bacterial count was determined according to FAD, (2005) using plate count method. MRS agar was used for the enumeration of Lactic acid bacteria incubated at $37^{\circ} \mathrm{C}$ for $48 \mathrm{~h}$ in sealed jar containing anaerobe sachet.

Staphylococcus aureus enumeration on Baird Parker agar supplemented with egg yolk tellurite medium incubated at $37^{\circ} \mathrm{C}$ for $48 \mathrm{~h}$. Yeast glucose chloramphenicol agar medium was used for yeast and molds enumeration were incubated at $25^{\circ} \mathrm{C}$ for 5 days. MacConkey Agar medium was used for the enumeration of coliform bacteria and fecal coliform were incubated at $37^{\circ} \mathrm{C}$ for $24 \mathrm{~h}$ for coliform bacteria and $44.5^{\circ} \mathrm{C}$ for $24 \mathrm{~h}$ for fecal coliform Mucchetti, et al (2008).

\subsection{Detection of Salmonella sp. and Shigella sp.}

The sample was mixed with sterile $1 \%$ peptone water in a ratio of $1: 10$ and incubated at $37^{\circ} \mathrm{C}$ for $24 \mathrm{hr}$. One $\mathrm{ml}$ of the pre-enriched broth was transferred to a sterile test tube containing $9 \mathrm{ml}$ Gramnegative broth (selenite broth) as an enrichment medium. The tubes were incubated for $16-18 \mathrm{~h}$ at $37^{\circ} \mathrm{C}$ after which a loopful from each enriched broth was streaked on the surface of both XLD and S.S. agar media to detect Shigella sp. The plates were incubated at $37^{\circ} \mathrm{C}$ for $24 \mathrm{hr}$. On XLD agar, Shigella sp colonies are red, on S.S. agar, Shigella $\mathrm{sp}$. gives translucent small colonies. While detection of Salmonella sp. a loopful from each enriched broth was streaked on the surface of both S.S agar, Brilliant green agar and Bismuth Sulfite Agar media. The plates were incubated inverted at $37^{\circ} \mathrm{C}$ for $24 \mathrm{hr}$. On S.S agar, Salmonella sp colony is small translucent with or without a black center, but on Brilliant green agar Salmonella sp colony is red purple surrounded by a red halo and tan to brown or black colonies on Bismuth Sulfite Agar medium.

\subsection{Detection of Campylobacter jejuni}

Two grams of each sample were transferred to $10 \mathrm{ml}$ of thioglycolate medium with Skirrow supplement (SR 69 , Oxoid) and incubated at $37^{\circ} \mathrm{C}$ for 24 hours under microaerophilic conditions $\left(6 \% \mathrm{O}_{2}\right.$ $+10 \% \mathrm{CO}_{2}$ ).

A loopful from each enriched broth was streaked on the surface of both Campylobacter blood agar base media (10\% sheep blood) and Campylobacter blood free selective agar base. The plates were incubated inverted at $43^{\circ} \mathrm{C}$ for 48 hours under microaerophilic conditions using gas generation kits specific for Campyobacter sp 


\subsection{Detection of Bacillus cereus}

The sample was mixed with sterile $1 \%$ peptone water in a ratio $1: 10$ and incubated at $37^{\circ} \mathrm{C}$ for $24 \mathrm{~h}$ to enrichment. After which a loopfull from each enriched broth was streaked on the surface of $\mathrm{Ba}$ cillus cereus Agar Base medium FAD (2005). The plates were incubated inverted at $37^{\circ} \mathrm{C}$ for $24 \mathrm{hr}$. Colonies appear turquoise to peacock blue colonies developed on PPEMPa and surrounded by a precipitate.

\subsection{Detection of Escherichia coli O157: H7}

Samples dilutions were spread onto plates of Sorbitol MacConkey agar medium (Oxoid, England). After $18-24 \mathrm{~h}$ at $35^{\circ} \mathrm{C}$ incubation, sorbitol negative colonies (pale - colored, typical E. coli 0157: H7) were serologically tested, as outlined by FAD (2005).

\subsection{Detection of Listeria monocytogenes}

Detection of Listeria monocytogenes was carried out according to the methods of FDA (2005). Twenty five grams from each sample were added to $225 \mathrm{ml}$ of listeria enrichment broth medium. Enrichment broth incubated at $30^{\circ} \mathrm{C}$ for 7 days. After that, $0.1 \mathrm{ml}$ of the inoculated enrichment broth culture was streaked on Palcam agar media incubated at $35^{\circ} \mathrm{C}$ for $24-48$ hours Hitchins (2003) and loopful from listeria enrichment broth culture was streaked on Oxford agar incubated at $37^{\circ} \mathrm{C}$ for 24 48 hours. Up to five typical colonies (dew-drop-like, dark brown or black colonies with brown or black halo).

The pathogenic detected were subjected to preliminary identification tests including Gram staining, catalase, MR/VP, gas production and coagulation....etc. and second identification by serological test at species level with Vitek 2 system Version: 07.01 (BioMérieux) in Air Force Specialized Hospital.

\section{RESULTS AND DISCUSSION}

\section{Microbial counts in Domaiti raw milk soft white cheeses}

Data in Table (1) show that the microbial count (cfu/g) in Tallaga soft white cheese, Istanbully, Double cream and Baramely soft white cheese from traditional dairy factories in Egypt.
Lactic Acid Bacteria (LAB) was $8.4 \times 10^{2}$, $8.1 \times 10^{2}, 12.9 \times 10^{3}$ and $3.1 \times 10^{3} \mathrm{cfu} / \mathrm{g}$ in Tallaga, Istanbully, Double cream and Baramely soft white cheese, respectively. These results were lower than results as reported by Beuvier and Buchin (2004) who found that lactic acid bacteria count was high $10^{8}-10^{9} \mathrm{cfu} / \mathrm{g}$, and regularly decreased during storage. LAB are biopreservatives, it produce a variety of inhibitory substances including hydrogen peroxide, diacetyl, carbon dioxide, ethanol and bacteriocins against the growth of pathogenic and spoilage microorganisms. LAB improve the safety and increase the quality of dairy products D'Amico et al (2010).

Total bacterial count (TBC) of different cheese samples were $9.2 \times 10^{5}, 5.7 \times 10^{4}, 7.4 \times 10^{5}$ and $8.2 \times 10^{5} \mathrm{cfu} / \mathrm{g}$ in Tallaga, Istanbully, Double cream and Baramely soft white cheese, respectively. These results were higher than results as reported by Anhar (1989) who found that TPC in Domiati white soft cheese aged for 1-3 months ranged from 5.3 to $9.6 \times 10^{5}$ with a mean of $8.2 \times 10^{5}$. Abdel Moneim et al (2016) found TBC in soft white cheese from camel and cow raw milk was $5.0 \times 10^{6}$ (cfu/g). The high TBC level in this study may be due to different factors such as: contaminated raw milk, unhygienic processing conditions and practices during milk collection.

Coliform bacteria may exist in cheese in large numbers; they have been used as indicators of unhygienic manufacturing practices. Total coliforms in cheese samples were $4.9 \times 10^{2}, 9.5 \times 10^{3}$, $7.4 \times 10^{3}$ and $4.1 \times 10^{3} \mathrm{cfu} / \mathrm{g}$ in Tallaga, Istanbully, Double cream and Baramely soft white cheese, respectively. These results were above the limits required by the Egyptian standards (10083/2005). In Egyptian standard requirements not exceed $10 \mathrm{cfu} / \mathrm{g}$.

Also, data in Table (1) show that fecal coliforms in cheese samples were $2.3 \times 10^{2}, 3.2 \times 10^{2}$, $4.1 \times 10^{2}$ and $3.1 \times 10^{2} \mathrm{cfu} / \mathrm{g}$ in Tallaga, Istanbully, Double cream and Baramely soft white cheese, respectively. These results were higher than results as reported by Ahmed et al (1988), who suggested that coliforms may lose their viability in Domiati cheese due to the inhibitory effect of salt, low $\mathrm{pH}$ value and competition with other microorganisms during ripening period. Trmcic et al (2016) found fecal $E$. coli in raw milk soft white cheese. The contamination with coliform and fecal $E$. coli indicates a need to improve efficient cleaning and sanitation program in cheese chain processing. Coliforms in soft white cheese. Coliform caused some diseases may include gastrointesti- 
nal illnesses such as severe diarrhea, nausea, and possibly jaundice as well as associated headaches and fatigue (CDFA, 2016).

Total yeast and molds in different cheese samples were $13.0 \times 10^{4}, 22.0 \times 10^{2}, 7.5 \times 10^{3}$ and $48.0 \times$ $10^{3} \mathrm{cfu} / \mathrm{g}$ in Tallaga, Istanbully, Double cream and Baramely soft white cheese, respectively. These results were above the limits required by the Egyptian standards (1008-3/2005) which should not exceed $10 \mathrm{cfu} / \mathrm{g}$ for fungi and $400 \mathrm{cfu} / \mathrm{g}$ for yeast. These results agree with the results reported by Abou Dawood et al., (2005) how found that many of Domiati cheese samples collected from Giza Government, contained higher counts of yeast and molds than the standard specifications. The presence of molds and yeasts in dairy products is undesirable hazard. It could be coms from the environmental factors such as: walls and shelves of ripening rooms, air, equipment, water, milk, brine, etc.

Enumeration of Staphylococcus sp in four kinds soft white cheese from traditional dairy factories in Egypt presented in Table (2). Cheese is a good substrate for growth of $S$. aureus and other pathogens. Such product is involved in foodborne diseases due to: the occurrence of coagulase-positive staphylococci in raw milk cheese; crosscontamination during the process; the possible cross-contamination thereafter (Addis and Kyule, 2011). Staphylococcus aureus in different cheese samples ranged from $1.6 \times 10^{2} \mathrm{cfu} / \mathrm{g}$ (Istanbully cheese) to $9.0 \times 10^{3} \mathrm{cfu} / \mathrm{g}$ (Baramely cheese). These results were higher than the limits required by the Egyptian standards (1008-3/2005). These are results lower than that found by El Kholy et al (2008) who found similar results for the incidence and counts of staphylococcus aureus in Tallaga soft white cheese samples collected from Cairo \& Giza areas during 2004 to 2005 reported that Staphylococcus aureus was detected in Domiati soft white cheese samples collected from different sites in Egypt. Nearly similar results obtained by Eid and Eltalawy (2014). Staphylococcal counts should reach approximately $10^{6} \mathrm{cfu} / \mathrm{g}^{-1}$ to be associated with enterotoxin production (Necidova et al 2009).

(Makita et al 2012) also isolated Staphylococcus aureus from soft white cheese. Staphylococcus aureus is often present on human skin and in nasal passages and is potentially a post processing contaminant.

\author{
Pathogenic bacteria in Domaiti soft white \\ cheeses
}

Data in Table (2) shows pathogenic bacteria (cfu/g) in Tallaga, Istanbully, Double cream and Baramely soft white cheese from traditional dairy Plants in Egypt. The absence of pathogens in Istanbully soft white cheese is a result of a salting level up to $16 \%$, which is an efficient control measure, regardless the environmental and health burdens. The contamination of other cheese types with the microbial pathogens (E. coli O157:H7, Salmonella sp, Shigella sp., Listeria monocytogenes, Bacillus cereus and Campylobacter jejuni) was observed in Table (2). These results were above the limits required by the Egyptian standards (1008-3/2005).

Addis et al (2012) obtained results that is in agreement with results in the presented study, they detected E. coli O157: $\mathrm{H} 7$ in feta soft white and Egyptian Domaiti soft white cheese. El Kholy et al (2008) and El Sayed et al (2011) found E. coli O157:H7 from white soft cheese samples. CDIC, 2014 found $E$. coli O157: $\mathrm{H} 7$ in raw milk soft white cheese. Many other researchers obtained similar results such as: detected Salmonella spp. in Domatii soft white cheese. El Kholy et al (2008) found Salmonella spp in Domatii soft white cheese, Listeria monocytogens in Tallaga soft white cheese samples collected from Cairo \& Giza areas during 2004 to 2005 . It is most likely due to post process contamination from environmental sources and cross-contamination in the dairy plant and or retail shops stores or processing chain. CDIC, (2013) found Listeria monocytogenes in refrigerators samples from retail stores at USA. Listeria monocytogenes can survive a number of cheese-making processes and can remain viable in the final product for a considerable length period of time (Griffiths, 1989). A combination of control measures was suggested to prevent, eliminate and reduce the contamination with microbial hazards to the safe limits.

\section{Physio-chemical composition in Domaiti soft white cheeses}

Data in Table (3) show that Physio-chemical composition in Tallaga, Istanbully, Double cream and Baramely soft white cheese from traditional dairy Plants in Egypt. Total protein (TP) content in soft white cheese samples were 11.30, 12.80 and $11.21 \%$ in Istanbully, Double cream and Baramely soft white cheese, respectively. These results were 
Table 1. Microbial count (cfu/g) in Domaiti raw milk soft white cheeses.

\begin{tabular}{|l|c|c|c|c|}
\hline \multirow{2}{*}{$\begin{array}{l}\text { Microbial Group } \\
\text { (cfu/g) } \pm{ }^{*} \text { SE }\end{array}$} & Tallaga & Istanbully & Double cream & Baramely \\
\cline { 2 - 5 } & $8.4 \times 10^{2} \pm 0.21$ & $8.1 \times 10^{2} \pm 0.53$ & $12.9 \times 10^{3} \pm 1.3$ & $3.1 \times 10^{3} \pm 0.66$ \\
\hline Lactic acid bacteria & $9.2 \times 10^{5} \pm 1.2$ & $5.7 \times 10^{4} \pm 2.81$ & $7.4 \times 10^{5} \pm 1.23$ & $8.2 \times 10^{5} \pm 1.31$ \\
Total bacterial count & $4.9 \times 10^{2} \pm 1.98$ & $9.5 \times 10^{3} \pm 51.0$ & $7.4 \times 10^{3} \pm 4.3$ & $4.1 \times 10^{3} \pm 0.8$ \\
Fecal E. coli & $2.3 \times 10^{2} \pm 6.34$ & $3.2 \times 10^{2} \pm 1.6$ & $4.1 \times 10^{2} \pm 0.83$ & $3.1 \times 10^{2} \pm 0.13$ \\
Yeast \& Molds & $13.0 \times 10^{4} \pm 0.08$ & $22.0 \times 10^{2} \pm 0.12$ & $7.5 \times 10^{3} \pm 0.23$ & $48.0 \times 10^{3} \pm 0.09$ \\
\hline
\end{tabular}

${ }^{*} \mathrm{SE}=$ Stander error

Table 2. Pathogenic bacteria (cfu/g) in Domaiti raw milk soft white cheeses

\begin{tabular}{|l|c|c|c|c|}
\hline \multirow{2}{*}{ Pathogenic bacteria $\pm{ }^{*} \mathrm{SE}$} & \multicolumn{3}{|c|}{ Cheese types } \\
\cline { 2 - 5 } & Tallaga & Istanbully & Double cream & Baramely \\
\hline Staphylococcus aureus & $1.9 \times 10^{2} \pm 0.164$ & $1.6 \times 10^{2} \pm 0.32$ & $7.0 \times 10^{3} \pm 0.98$ & $9.0 \times 10^{3} \pm 0.72$ \\
E. coli 0157:H7 & $\mathrm{ND}$ & $\mathrm{ND}$ & + & $\mathrm{ND}$ \\
Salmonella typhi & + & $\mathrm{ND}$ & + & + \\
Shigella sp. & + & $\mathrm{ND}$ & $\mathrm{ND}$ & + \\
Listeria monocytogenes & + & $\mathrm{ND}$ & $\mathrm{ND}$ & + \\
Bacillus cereus & $\mathrm{ND}$ & $\mathrm{ND}$ & $\mathrm{ND}$ & $\mathrm{ND}$ \\
Campylobacter jejuni & + & $\mathrm{ND}$ & $\mathrm{ND}$ & $\mathrm{ND}$ \\
\hline
\end{tabular}

${ }^{*} \mathrm{ND}=$ Not detected $\quad{ }^{*} \mathrm{SE}=$ Stander error 
Table 3. Physio-chemical composition in Domaiti soft white cheeses

\begin{tabular}{|lcccc|}
\hline \multirow{2}{*}{ Composition $\pm{ }^{*}$ SE } & \multicolumn{4}{c|}{ Cheese types } \\
\cline { 2 - 5 } & Tallaga & Istanbully & Double cream & Baramely \\
\hline Protein \% & $9.60 \pm 0.57$ & $11.30 \pm 0.37$ & $12.80 \pm 0.19$ & $11.21 \pm 0.62$ \\
Fat \% & $16.80 \pm 0.21$ & $20.70 \pm 0.24$ & $19.50 \pm 0.81$ & $21.00 \pm 0.32$ \\
Moisture \% & $65.00 \pm 0.15$ & $60.50 \pm 0.12$ & $62.80 \pm 0.03$ & $61.00 \pm 0.07$ \\
Total solid\% & $35.00 \pm 0.02$ & $40.00 \pm 0.04$ & $37.20 \pm 0.18$ & $39.00 \pm 0.38$ \\
Ash \% & $12.40 \pm 0.10$ & $13.70 \pm 0.14$ & $12.60 \pm 0.25$ & $11.80 \pm 0.01$ \\
NaCl \% & $10.60 \pm 0.04$ & $13.20 \pm 0.03$ & $11.80 \pm 0.16$ & $12.60 \pm 0.35$ \\
pH & $4.30 \pm 0.08$ & $3.60 \pm 0.01$ & $3.80 \pm 0.03$ & $3.20 \pm 0.19$ \\
Acidity \% & $0.47 \pm 0.05$ & $0.98 \pm 0.14$ & $0.68 \pm 0.07$ & $1.30 \pm 0.02$ \\
EC $(\boldsymbol{\mu}$ ) & $16.20 \pm 0.04$ & $34.4 \pm 0.02$ & $23.40 \pm 0.06$ & $26.20 \pm 0.05$ \\
\hline
\end{tabular}

${ }^{*} \mathrm{SE}=$ Stander error

above limit of protein content required by Egyptian standards (3-1008/2005) which should be $10 \%$ at least. Total protein in Tallaga cheese was $9.6 \%$, these results were below limit Egyptian standards (1008-3/2005). The results reported by AbouDawood et al (2005) emphasized that a mean of total protein of Domiati cheese was $7.89 \%$. The results were lower than that reported by Dabiza et al (1999) and Ojedapo et al (2014) who reported that TP of soft white cheese ranged from 17.7 to $20.5 \%$. Concerning the fat content, in soft white cheese samples were 16.80, 20.70, 19.50 and $21.00 \%$ in Tallaga, Istanbully, Double cream and Baramely soft white cheese, respectively. These results were less than limit of fat content required by Egyptian standards (1008-3/2005) which should be in rang $45-60 \%$ fat and in agreement with the results reported by Idris (1989) and Ojedapo et al (2014) whose found that fat content of Domatii soft white cheese ranged from 14.00 to 15.31 with a mean of $14.46 \%$. Hofi et al (2010) found that fat content of Domiati soft white cheese ranged from 38.70 to 51.50 with a mean of $45.50 \%$. Low of fat percentage in cheese samples may be due to distributor of milk is remove and segregate fat from milk to made butter for high prices.
The total solids (TS) of soft white cheese samples ranged from $35.00,37.00 \%$ for $39.00 \%$ in Tallaga cheese, Double cream, and Baramely cheese, respectively. These results were lower than results as reported by El-Kenany et al (2001) who found that total solids of fresh Domiati cheese was $43.27 \%$. While the total solid in Istanbully cheese was $40.0 \%$ this result was agreement with the limits required by Egyptian standards (1008-

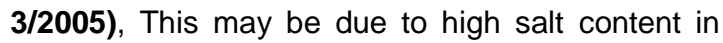
Istanbul soft white cheese or add additives such as powder milk.

The $\mathrm{pH}$ values in soft white cheese samples were 4.30, 3.80, 3.60, and 3.20 in Tallaga, Double cream, Istanbully and Baramely soft white cheese, respectively. These results were lower than results reported by Anhar (1989) who found that $\mathrm{pH}$ values of Domiati soft white cheese ranged from 5.6 to 5.8 with a mean of 5.72. Also, Hofi et al (1975) found that $\mathrm{pH}$ values of Domiati soft white cheese ranged from 4.5 to 4.8 with a mean of 4.6 . The $\mathrm{pH}$ of soft white cheese reflected the change in acidity. The relatively decreased $\mathrm{pH}$ of soft white cheese samples in this study may be attributed to the fact that they were made from raw milk with high level of natural microflora. 
The acidity developed in Tallaga cheese $(0.47 \%)$ and Double Cream cheese $(0.68 \%)$ are lower than measured in Baramely soft white and Istanbully soft white cheese $(1.30 \%$ and $0.98 \%$, respectively). These results identified Istanbully soft white as a cheese with salt and acidity levels controlling the microbial hazards (Abou-Dawood et al 2005).

In this type of cheese, sodium chloride $(\mathrm{NaCl})$ is normally added to milk before renneting (Abd ElSalam et al 1976). Salt content in cheese samples were 10.60, 13.20, 11.80 and $12.60 \%$ in Tallaga, Istanbully, Double cream and Baramely soft white cheese, respectively. These results were above the limits required by the Egyptian standards (1008-3/2005) which should not exceeded $9 \%$. These results were higher than the results reported by Abou-Dawood et al (2005) who found that salt content of Domiati cheese ranged from 3.0 to 6.0 with a mean of 4.2 . The relation between salt content and cheese quality could be explained on the basis that the high salt content would interfere with normal ripening processes. Besides it would overcome the sensory effect of the flavor constituents (Hofi et al 1975). The ash content is reflecting the salt content of cheese samples which were $12.40,13.70,12.60$ and $11.80 \%$ in Tallaga, Istanbully, Double cream and Baramely soft white cheese, respectively. These results were higher than the results reported by Idris et al (1989) who found that ash content of Domiati soft white cheese ranged from 8.10 to 10.07 with a mean of $9.13 \%$.

\section{CONCLUSION}

In conclusion, it can be said that the raw milk cheese in the study area was satisfactory. It is confirmed by the high values of total bacterial count, Coliform, Staph. aureus and yeasts \& molds counts. Soft cheeses might represent a health risk for the consumers and considered as a possible vehicle of infection or vehicle of transmission for well stablished pathogens so the cheese made in street, farmers' home or in unlicensed factories is not safe for human consumption. More and more of proper inspection must be done on street markets, supermarkets, stores, factories, unlicensed factories of dairy products. The development and application of microbiological hazard must follow established basic principles to control presence or growth of pathogenic microorganisms.

\section{REFERENCES}

Abd El-Salam, M.H., El Shibiny, S. and Fahmi, A.H. 1976. Domiati cheese. A review. NZ. J. Dairy Sci. and Tech, 11-57.

Abdel Moneim, E.S., Siddig, S.M. and Salih, Z.A. 2016. Microbiological Characteristics and Sensory Evaluation of White Cheese Produced by Using Camel Milk and Mixture of Camel and Cow Milk. J. of Microbiology Research, 6(1), 8-13.

Abou-Dawood, A.I., Taha S.H. and Mohamed, M.A. 2005. Chemical and microbiological quality of raw milk, soft and hard cheese collected from some districts at Giza Governorate. Egypt. J. Dairy Sci., 33, 201-214.

Addis, M., Pal, M. and Kyule, N. 2011. Isolation of E.coli, Staphylococcus aureus and Listeria monocytogenes Identification of Staphylococcus species from Raw Bovine from Milk in Debre Zeit, Ethiopia. Vet. Res., 4(2), 45-49.

Addis, Z., Kebede, N., Worku, Z., Gezahegan H., Yirsaw, A. and Kassa, T. 2012. Prevalence and antimicrobial resistance of E. coli O157: H7 and Salmonella isolated from lactating cows and in contact humans in dairy farms of Addis Ababa: A cross sectional study. BMC Infectious Diseases, pp. 11- 22.

Ahmed, A.A.H., Ahmed, S.H. and Moustafa, M.K. 1988. Occurrence of fecal coliforms and enteropathoegnic Escherichia coli (EEC) in Egyptian soft cheese J. of Food Prot., 51(6), 442-444.

AOAC. 2006. Official Methods of Analysis $\left(16^{\text {th }}\right.$ ed.). Association of Official Analytical Chemists, (AOAC), Benjamin Franklin Station, Washington, D.C. USA.

Anhar, M.I. 1989. Yield, composition and coagulation time of unsalted soft cheese prepared from the milk of white Fulani cows. Int. J. of Current Microbiology and Applied Sci., 3, 378-383.

Anhar, M.I. 1989. Incidence of some harmful substances in some dairy products. M.Sc. Thesis, Dept. Food science. Fac. Agric., Ain Shams Univ., Egypt, pp. 63-71.

APHA. 1992. Standard Methods for the examination of dairy products. (16 ${ }^{\text {th }}$ ed.). American Public Health Association "APAH", Washington, D.C. USA.

Beuvier, E. and Buchin, S. 2004. Raw milk cheeses. In: Cheese: Chemistry, Physics and Microbiology Fox, P.F., McSweeney, P.H., 
Cogan, T.M., Guinee T.P. (ed.), Vol. 1, General Aspects. London: Academic press, pp. 319347.

CDFA .2016. California Milk Standards, Bacteriological Standards. Availablet at: https://www.cdfa.ca.gov

CDC 2013. Listeria (Listeriosis). http://www.cdc.gov

CDIC 2014. Global consumption per capita of dairy products: Total cheese consumption. http://www.dairyinfo.gc.ca

D'Amico, D., Druart, M. and Donnelly, C.W. 2010. Behavior of Escherichia coli O157:H7 during the manufacture and aging of Gouda and stirred-curd Cheddar cheese manufactured from raw milk. J. Food Prot. 73(12), 22172233.

Dabiza, N.M.A., El-Senaity, M.H. and Zin El-Dein, M.M. 1999. Pesticide residues in some market dairy products and distribution of malathion in butter; ghee and Domiati cheese during manufacture. Egypt. J. Dairy Sci., 27(2), 345-358.

De Buyser, M.L., Dufour, B., Maire, M. and Lafarge, V. 2001. Implication of milk and milk products in food-borne diseases in France and in different industrialised countries. Int. J. of Food Microbiology, 67, 1-17.

Egyptian Standards for Domiati Cheese. 2000. Egyptian Organization for Standards and Quality Controls. ES:1008-3/2005.

Eid, A.M. and Eltalawy, M.F. 2014. Enterotoxogenic Staphylococcus aureus isolated from soft cheese. Benha Veterinary Medical Journal, 27(2), 444- 448.

EI Kholy, W.I., Hosny, I.M. and El Dairouty, R.K. 2008. Rapid microbiological analysis and foodborne microorganisms in Tallaga cheese. Egyptian J. Dairy Sci. 36, 73-82.

El-Baradei, G., Delacroix, A.B. and Ogier, J. 2007a. Biodiversity of Bacterial Ecosystems in Traditional Egyptian Domiati Cheese Appl. and Enviro. Microbiol., 73, 1248-1255.

El-Baradei, G., Delacroix, A. B. and Ogier, J. 2007b. Economics scale for processing of white soft cheese in Egypt. Egypt. J. Agric. Econ., 21, 1079-1094.

El-Hofi, M., El-Tanboly, E. and Ismail, A. 2010. Implementation of the Hazard Analysis Critical Control Point (Haccp) System to Uf White Cheese Production Line. Acta Sci. Pol., Technol. Aliment. 9(3), 331-342.
El-Kenany, Y.M., Karima, A.M., Abou El-E.M., Farag, A. and El-Nawawy, M.A. 2001. Hazard assessment of some metals in white pickled cheese in Egypt. Proc. $8^{\text {th }}$ Egyp. Conf. Dairy Sci. and Techn., pp. 595-607.

El-Sayed, A.M., Hosney, I.M., EL-Kholy, W.I., EL-Dairouty, A.M. and Sahar, H.M. $2011 \mathrm{Mi}-$ crobiological evaluation of Egyptian white soft cheeses style. J. of American Sci., 7(5), 517526.

FAD. 2005. 'food code' united states department of health and human services. http:/www.cfsan. fda.gov

Gould, L.H., Mungai, E. and Behravesh, C.B. 2014. Outbreaks attributed to cheese: Differences between outbreaks caused by unpasteurized and pasteurized dairy products, United States, 1998-2011. Foodborne Pathog. Dis. 11, 545-551.

Griffiths, M.W. 1989. Listeria monocytogenes: Its importance in dairy industry. J. Sci. Food Agric. 47, 133-158.

Hegazy, N.M., Nasr, M.M., Fayed, A.E. and Youssef, M.S. 2012. Economics scale for processing of white soft cheese in Egypt. Egypt. J. Agric. Econ., 21, 1079-1094.

Hegazy, M.I. and Mahgoub, S.A. 2013. Microbiological characterization of the Egyptian soft white cheese and identification of its dominant yeasts. African Journal of Microbiology 3(3), 522-529.

Hitchins, A.D. 2003. Detection and enumeration of Listeria monocytogenes in foods. US Food and Drug Administration's Bacteriological Analytical Manual. Chapter 1, 10-15.

Hofi, A.A., Safinaz, E., Mahran, G.A., Farahat S.M. and. Abdel Baky, A.A. 1975. The quality and chemical composition of market domiati cheese. Egypt. J. Dairy Sci., 3(2), 135-138.

Makita, K., Desissa, F., Teklu, A., Zewde, G. and Grace, D. 2012. Risk assessment of staphylococcal poisoning due to consumption of informally-marketed milk and home-made yoghurt in Debre Zeit, Ethiopia. Int. J. Food Microbiol. 153, 135-141.

Mucchetti, G., Bonvini, B., Remagni, M.C., Ghiglietti, R., Locci, F. and Barzaghi, S. 2008. Influence of cheese-making technology on composition and microbiological characteristics of Vastedda cheese. Food Control.,19, 119-125. 
Necidova, L., Stastkova, Z., Pospisilova, M., Janstova, B., Strejcek, J., Duskova, M. and Karpiskova, R. 2009. Influence of soft cheese technology on the growth and enterotoxin production of Staphylococcus aureus. Czech J. Food Sci., 27, 127-133.

Nummer, F.K., Jokey, R.O., Allius, G. and Mestvn, R. 2012. Implication of milk and milk products in food-borne diseases in France and in different industrialised countries. Int. J. of Food Microbiology, 67, 1-17.
Ojedapo, L.O., Tona, G.O., Amao, S.R. and Adeneye, J.A. 2014. Yield, composition and coagulation time of unsalted soft cheese prepared from the milk of white Fulani cows. Int. J. of Current Microbiology and Applied Sci., 3, 378-383.

Trmčić, A., Chauhan, K., Kent, D.J., Ralyea, R.D., Martin, N.H. and Boor, K.J. 2016. Coliform detection in cheese is associated with specific cheese characteristics, but no association was found with pathogen detection. J. Dairy Sci., 99, 1-16. 